\title{
Article \\ Effects of Cultivar, Nitrogen Rate and Harvest Time on the Content of Carbohydrates and Protein in the Biomass of Perennial Ryegrass
}

\author{
Marzenna Olszewska (D)
}

check for updates

Citation: Olszewska, M. Effects of Cultivar, Nitrogen Rate and Harvest Time on the Content of Carbohydrates and Protein in the Biomass of Perennial Ryegrass. Agronomy 2021, 11, 468. https:// doi.org/10.3390/agronomy11030468

Academic Editor: Stefano Amaducci

Received: 27 January 2021

Accepted: 26 February 2021

Published: 4 March 2021

Publisher's Note: MDPI stays neutra with regard to jurisdictional claims in published maps and institutional affiliations.

Copyright: (C) 2021 by the author. Licensee MDPI, Basel, Switzerland. This article is an open access article distributed under the terms and conditions of the Creative Commons Attribution (CC BY) license (https:// creativecommons.org/licenses/by/ $4.0 /)$.
Department of Agrotechnology and Agribusiness, University of Warmia and Mazury in Olsztyn, 10-719 Olsztyn, Poland; marzenna.olszewska@uwm.edu.pl

\begin{abstract}
The aim of this study was to determine the effects of cultivar, nitrogen $(\mathrm{N})$ rate and harvest time on the content of water-soluble carbohydrates (WSC), crude protein (CP) and the WSC:CP ratio in the aboveground biomass of perennial ryegrass (Lolium perenne L.). A small-area field experiment was conducted in the Agricultural Experiment Station in Tomaszkowo (53 $42^{\prime} 40.8^{\prime \prime} \mathrm{N} 20^{\circ} 26^{\prime} 04.7^{\prime \prime}$ E, north-eastern Poland). Data were presented for three years of full utilization (2013-2015). The experimental factors were as follows: (i) perennial ryegrass cultivar: Bajka and Baronka, (ii) $\mathrm{N}$ rate $\left(\mathrm{kg} \mathrm{ha}^{-1}\right)$ : 0, 120, and 240, and (iii) harvest time: 8.00-10.00 a.m., 12.00-2.00 p.m., and 4.00-6.00 p.m. The tetraploid cultivar Baronka had higher WSC content and lower CP content on a dry matter (DM) basis than the diploid cultivar Bajka (by approx. $3 \%$ on average). An increase in $\mathrm{N}$ fertilizer rate to $240 \mathrm{~kg} \mathrm{ha}^{-1}$ contributed to a decrease in WSC concentrations by $23 \%$ in cv. Bajka and by $19 \%$ in cv. Baronka, and to an increase in the CP content of aboveground biomass by $32 \%$ and $23 \%$, respectively. Both cultivars accumulated significantly higher WSC amounts when biomass was harvested at noon and in the afternoon than in the morning. The CP content of biomass was also affected by harvest time, and it was higher in cv. Bajka when harvesting was carried out at 12.00-2.00 p.m. and 4.00-6.00 p.m., and in cv. Baronka when harvesting was carried out at 4.00-6.00 p.m. The WSC:CP ratio in the biomass of the analyzed cultivars was within the optimal range for ruminants, and it was higher in cv. Baronka (1:1.11). Nitrogen applied at $240 \mathrm{~kg} \mathrm{ha}^{-1}$ had a negative influence on the WSC:CP ratio, decreasing its value by around $36 \%$ (relative to the rate of $120 \mathrm{~kg} \mathrm{~N} \mathrm{ha}^{-1}$ ) and around $35 \%$ (relative to the unfertilized treatment). In both perennial ryegrass cultivars, biomass harvested in the morning was characterized by the lowest WSC:CP ratio.
\end{abstract}

Keywords: perennial ryegrass; carbohydrates; protein; cultivar; nitrogen; harvest

\section{Introduction}

In order to successfully compete with other types of roughage, green fodder should be characterized by high concentrations of digestible energy, palatability and optimal crude protein (CP) content, and it should be well suited to the unique digestive system of ruminants [1]. Water soluble carbohydrates (WSC) are a major source of readily available energy required by rumen microbes [2]. They are accumulated in the roots, shoots, leaf sheaths and leaf blades of plants [3]. Water soluble carbohydrate reserves affect the rate of grass regeneration and regrowth after defoliation, and contribute to successful winter survival [4]. They also determine the palatability and intake of green fodder [2]. Jones and Roberts [5] compared four perennial ryegrass (Lolium perenne L.) cultivars characterized by similar digestibility but differing in WSC concentrations, and found that cultivars with high WSC content were more palatable than cultivars with moderate WSC content.

The WSC content of grass biomass varies widely because it is affected by various factors such as plant part, growth stage, growth rate, season, temperature, light intensity, water availability, species, cultivar and ploidy level as well as fertilization [6,7]. The WSC content of grasses is higher in early growth stages than during stem elongation and heading. 
Rapidly growing plants need large amounts of carbohydrates to produce aboveground biomass. Therefore, late slow-growing cultivars have higher WSC content than early fastgrowing cultivars [8]. Between heading and flowering, the WSC content of plants remains relatively stable, and then it increases during milky development $[9,10]$. There is a negative correlation between an increase in temperature and the WSC content of grasses. In summer, the WSC content of biomass decreases due to unfavorable hydrothermal conditions. The concentration of WSC is also affected by ploidy, and it is higher in tetraploid than in diploid cultivars $[7,11,12]$. An important role is also played by fertilization, in particular nitrogen $(\mathrm{N})$ fertilizers. Nitrogen stimulates life processes in plants and increases yields, but it also has a negative effect on WSC accumulation.

Animals fed grasses with high WSC content more effectively utilize dietary $\mathrm{CP}$, which increases body weight gains and milk yields [7,13-19]. Feed deficient in WSC can lead to considerable CP losses due to disruption of microbial fermentation in the rumen $[1,20,21]$. Increased feed intake and improved nutrient utilization are dependent upon accelerated microbial metabolism in the rumen, which can be achieved at an optimal WSC:CP ratio [22-25]. The WSC:CP ratio affects dietary protein availability and $\mathrm{N}$ use efficiency [26-28].

The aim of this study was to determine the effects of cultivar, $\mathrm{N}$ rate and harvest time on the content of WSC, CP and the WSC:CP ratio in the aboveground biomass of perennial ryegrass. The research hypothesis postulates that different $\mathrm{N}$ rates significantly affect the $\mathrm{CP}$ content of perennial ryegrass biomass, and harvest time and ploidy significantly affect the concentrations of WSC and CP in biomass. The determination of the optimal harvest time and the appropriate selection of cultivars contribute to increasing the WSC content of biomass and producing forage characterized by high energy value and a desirable WSC:CP ratio, without increasing production costs.

\section{Materials and Methods}

\subsection{Field Experiment}

A small-area field experiment was conducted in the Agricultural Experiment Station in Tomaszkowo (53 $42^{\prime} 40.8^{\prime \prime} \mathrm{N} 20^{\circ} 26^{\prime} 04.7^{\prime \prime}$ E, north-eastern Poland), owned by the University of Warmia and Mazury in Olsztyn. The experiment, established at the end of August in 2012, had a split-plot design with four replications. The following variables were tested: (i) perennial ryegrass cultivar: Bajka and Baronka, (ii) $\mathrm{N}$ rate $\left(\mathrm{kg} \mathrm{ha}^{-1}\right): 0,120$, and 240, and (iii) harvest time: $8.00-10.00$ a.m., $12.00-2.00$ p.m., and 4.00-6.00 p.m. Seeding rates were 27 (cv. Bajka) and $38 \mathrm{~kg} \mathrm{ha}^{-1}$ (cv. Baronka). Harvested plot size was $10 \mathrm{~m}^{2}$. The experiment was established on Haplic Cambisol (Eutric) originating from boulder clay [29]. Composite soil samples were collected from each plot to a depth of $20 \mathrm{~cm}$ to determine the chemical properties of soil. The soil had a neutral $\mathrm{pH}$ of 6.6, and it was characterized by a moderate content of available phosphorus (50.6 mg P kg${ }^{-1}$ ) and potassium (120.4 $\mathrm{mg} \mathrm{K} \mathrm{kg}^{-1}$ ), and low magnesium content $\left(46.0 \mathrm{mg} \mathrm{Mg} \mathrm{kg}^{-1}\right)$. The soil was moderately abundant in micronutrients (148.0 $\mathrm{mg} \mathrm{Mn} \mathrm{kg}^{-1}, 3.0 \mathrm{mg} \mathrm{Cu} \mathrm{kg}^{-1}, 7.8 \mathrm{mg} \mathrm{Zn} \mathrm{kg}^{-1}$ and $1400.0 \mathrm{mg} \mathrm{Fe} \mathrm{kg}^{-1}$ ). Soil $\mathrm{pH}$ was measured using a digital $\mathrm{pH}$ meter with temperature compensation $\left(20^{\circ} \mathrm{C}\right)$ in deionized water and $1 \mathrm{~mol} \mathrm{dm}{ }^{-3} \mathrm{KCl}$, at a 5:1 ratio. Plant-available $\mathrm{P}$ and $\mathrm{K}$ were measured by the Egner-Riehm method. Phosphorus was determined by the colorimetric method (ultraviolet (UV)-1201V spectrophotometer, Shimadzu Corporation Kyoto, Japan), and $\mathrm{K}$ was determined by atomic emission spectrometry (AES) (Flame Photometers, BWB TechnologiesLtd., Newbury, UK). Magnesium was determined by atomic absorption spectrophotometry (AAS) (AAS1N, Carl Zeiss Jena, Germany). Micronutrients (Cu, Zn, Mn and $\mathrm{Fe}$ ) were determined by AAS (AA-6800, Shimadzu Corporation Kyoto, Japan). Before the establishment of the experiment, $\mathrm{P}$ fertilizer was applied at $35 \mathrm{~kg} \mathrm{ha}^{-1}$ (enriched superphosphate, $40 \% \mathrm{P}_{2} \mathrm{O}_{5}$ ) and $\mathrm{K}$ fertilizer was applied at $50 \mathrm{~kg} \mathrm{ha}^{-1}$ (potassium salt, $60 \% \mathrm{~K}_{2} \mathrm{O}$ ). In the years of full utilization, the treatments were fertilized with $35 \mathrm{~kg} \mathrm{P} \cdot \mathrm{ha}^{-1}$ (enriched superphosphate, $40 \% \mathrm{P}_{2} \mathrm{O}_{5}$ ) and $100 \mathrm{~kg} \mathrm{~K} \cdot \mathrm{ha}^{-1}$ (potassium salt, $60 \% \mathrm{~K}_{2} \mathrm{O}$ ). Phosphorus was applied at a single rate in early spring (at the beginning of the growing season), and the 
rate of $\mathrm{K}$ fertilizer was split into two equal doses and applied in spring (at the beginning of the growing season) and after the 1st harvest. Nitrogen (ammonium nitrate, $34 \% \mathrm{~N}$ ) was applied in spring (before the growing season) and after each harvest (I-IV), splitting the rate into four equal doses. First-cut herbage was harvested at the beginning of heading of cv. Baronka, the second harvest was carried out 5 weeks after the first harvest, the third harvest was carried out 6 weeks after the second harvest, and the fourth harvest was carried out 7 weeks after the third harvest.

In order to determine the variability of weather conditions during the growing seasons, Sielianinov's hydrothermal index was calculated using Equation (1) [30]:

$$
\mathrm{k}=\frac{\mathrm{P}}{0.1 \sum \mathrm{t}}
$$

where:

$\mathrm{P}$-total monthly precipitation,

$\Sigma \mathrm{t}$-mean monthly temperature (sum of mean daily temperatures) $>0$.

Hydrothermal conditions were evaluated based on the classification of index $\mathrm{k}$ values, proposed by Skowera and Puła [30]: extremely dry (ed) $\mathrm{k} \leq 0.4$, very dry (vd) $0.4<\mathrm{k} \leq 0.7$, dry (d) $0.7<\mathrm{k} \leq 1.0$, fairly dry (fd) $1.0<\mathrm{k} \leq 1.3$, optimal (o) $1.3<\mathrm{k} \leq 1.6$, fairly wet (fw) $1.6<\mathrm{k} \leq 2.0$, wet (w) $2.0<\mathrm{k} \leq 2.5$, very wet (vw) $2.5<\mathrm{k} \leq 3.0$, extremely wet (ew) k > 3.0.

\subsection{Plant Materials}

One-kilogram biomass samples were collected after each harvest to analyze the chemical composition of plants. Dry matter (DM) content of biomass was estimated by drying a subsample of $1 \mathrm{~kg}$ at $105^{\circ} \mathrm{C}$ in a ventilated oven (FD 53 Binder GmbH, Tuttlingen, Germany) until constant weight. The WSC content was determined by the anthrone method [31] using the Eppoll-20 photometer (Poll Ltd., Warsaw, Poland), and CP content was determined by the Kjeldahl method [32]. Data were presented for three years of full utilization (2013-2015).

\subsection{Statistical Analysis}

The results were processed statistically by repeated measures ANOVA. The grouping factors were cultivar, $\mathrm{N}$ rate and harvest time, and harvest was the repeated measures factor. The assumption of sphericity, i.e., the condition where the variances of the differences between all pairs of repeated measures are equal, was validated by Mauchly's test. When this condition was not met, the univariate analysis was replaced with a multivariate analysis involving Wilks' Lambda. The significance of differences between treatment means was determined by Tukey's test at $p<0.05$. All calculations were performed using Statistica 13.3 software [33].

\section{Results and Discussion}

\subsection{Weather Conditions}

The growing season of 2013 was characterized by highly variable weather conditions. A water deficit was noted in May and June $(\mathrm{k}=1.2)$, followed by considerable rainfall deficiency in August ( $\mathrm{k}=0.7)$ and October $(\mathrm{k}=0.57)$. July was wet $(\mathrm{k}=2.2)$, and September was very wet $(\mathrm{k}=3.0)$. In 2014 , only August was characterized by optimal weather conditions $(\mathrm{k}=1.6)$, and the remaining months of the growing season were fairly dry $(k=1.0)$ or very dry $(k=0.55)$. The distribution of rainfall was uneven also in the third growing season (2015). Optimal weather conditions were observed in July $(\mathrm{k}=1.5)$ and September $(\mathrm{k}=1.6)$. Severe moisture deficits were noted in May $(\mathrm{k}=0.8)$, June $(\mathrm{k}=0.6)$ and August $(\mathrm{k}=0.2)$ (Table 1). 
Table 1. Sielianinov's hydrothermal index during the growing season.

\begin{tabular}{cccccccc}
\hline \multirow{2}{*}{ Years of the Study } & \multicolumn{9}{c}{ Month } \\
\cline { 2 - 7 } & April & May & June & July & August & September & November \\
\hline 2013 & $1.6(\mathrm{o})$ & $1.2(\mathrm{fd})$ & $1.2(\mathrm{fd})$ & $2.2(\mathrm{w})$ & $0.7(\mathrm{~d})$ & $3.0(\mathrm{vw})$ & $0.57(\mathrm{vd})$ \\
2014 & $1.0(\mathrm{fd})$ & $0.8(\mathrm{~d})$ & $1.2(\mathrm{fd})$ & $0.6(\mathrm{vd})$ & $1.6(\mathrm{o})$ & $0.6(\mathrm{vd})$ & $0.55(\mathrm{vd})$ \\
2015 & $1.9(\mathrm{fw})$ & $0.8(\mathrm{~d})$ & $0.6(\mathrm{vd})$ & $1.5(\mathrm{o})$ & $0.2(\mathrm{ed})$ & $1.6(\mathrm{o})$ & $1.02(\mathrm{fd})$ \\
\hline
\end{tabular}

\subsection{Water-Soluble Carbohydrates (WSC)}

An analysis of the mean values over three years revealed that WSC content was higher (by approx. $3 \%$ ) in the tetraploid cultivar Baronka than in the diploid cultivar Bajka. In the first year of the study, WSC content was significantly higher in the biomass of cv. Bajka. In the third year of the study, no significant differences in WSC concentrations were found between the cultivars. The greatest difference in WSC content between the cultivars (approximately $10 \%$ ) was noted in the second year of full utilization (Table 2). The observed differences in WSC accumulation could result from highly variable weather conditions in the experimental years. In 2014, characterized by considerable water deficit during the growing season, the tetraploid cultivar Baronka accumulated larger amounts of WSC. An increase in WSC content changes the osmotic potential of cells, which affects the rate of water uptake by plants and is a physiological mechanism underlying plant responses to drought stress [34-36]. The key role played by WSC in plant protection against water stress has been described by many authors [37-39]. Previous research $[2,7,12,40]$ has shown that tetraploid cultivars of perennial ryegrass have considerably higher WSC content than diploid cultivars, which is reflected in higher digestible energy value, higher digestibility and palatability of forage. In a study by Hume et al. [40], the concentrations of WSC were on average $19 \%$ higher in tetraploid cultivars of selected ryegrasses, compared with diploid cultivars. Gilliland et al. [7] demonstrated that the effect of ploidy on WSC concentrations can be modified by genetic factors. Smith et al. [12] analyzed tetraploid perennial ryegrass cultivars derived from diploid cultivars that had previously been selected for increased WSC content and found that tetraploids were not characterized by higher WSC concentrations than the respective diploids.

Table 2. Content of water-soluble carbohydrates in perennial ryegrass biomass $\left(\mathrm{g} \mathrm{kg}^{-1} \mathrm{dry}\right.$ matter (DM)).

\begin{tabular}{|c|c|c|c|c|}
\hline \multirow{2}{*}{ Parameter } & \multicolumn{3}{|c|}{ Years of the Study } & \multirow{2}{*}{ Mean } \\
\hline & 2013 & 2014 & 2015 & \\
\hline \multicolumn{5}{|c|}{ Cultivar } \\
\hline Baronka & $129.8^{\mathrm{a}}$ & $189.0^{\mathrm{b}}$ & $126.1^{\mathrm{a}}$ & $148.3^{b}$ \\
\hline Bajka & $134.9^{\mathrm{b}}$ & $170.7^{\mathrm{a}}$ & $126.9^{\mathrm{a}}$ & $144.2^{\mathrm{a}}$ \\
\hline \multicolumn{5}{|c|}{ Nitrogen rate $\left(\mathrm{kg} \mathrm{ha}^{-1}\right)$} \\
\hline 0 & $139.5^{\mathrm{b}}$ & $177.2^{b}$ & $147.4^{\mathrm{c}}$ & $154.1^{\mathrm{b}}$ \\
\hline 120 & $143.5^{b}$ & $200.7^{c}$ & $132.7^{b}$ & $159.2^{\mathrm{C}}$ \\
\hline 240 & $114.1^{\mathrm{a}}$ & $161.8^{\mathrm{a}}$ & $100.8^{a}$ & $125.5^{\mathrm{a}}$ \\
\hline \multicolumn{5}{|c|}{ Harvest time } \\
\hline 8.00-10.00 a.m. & $117.7^{\mathrm{a}}$ & $177.9^{\mathrm{a}}$ & $127.4^{\mathrm{a}}$ & $141.2^{\mathrm{a}}$ \\
\hline 12.00-2.00 p.m. & $141.4^{\mathrm{b}}$ & $181.3^{\mathrm{a}}$ & $124.4^{\mathrm{a}}$ & $149.1^{\mathrm{b}}$ \\
\hline $4.00-6.00$ p.m. & $138.0^{\mathrm{b}}$ & $180.4^{\mathrm{a}}$ & $127.8^{\mathrm{a}}$ & $148.5^{b}$ \\
\hline \multicolumn{5}{|c|}{ Harvest } \\
\hline I & $122.3^{b}$ & $256.1^{\mathrm{c}}$ & $200.4^{\mathrm{d}}$ & $192.9^{\mathrm{C}}$ \\
\hline II & $147.5^{\mathrm{c}}$ & $185.2^{b}$ & $111.6^{\mathrm{c}}$ & $148.1^{b}$ \\
\hline III & $102.5^{\mathrm{a}}$ & $96.3^{a}$ & $88.6^{\mathrm{a}}$ & $95.8^{\mathrm{a}}$ \\
\hline IV & $157.3^{\mathrm{d}}$ & $181.9^{b}$ & $105.3^{b}$ & $148.2^{b}$ \\
\hline
\end{tabular}

Means with the same letter do not differ significantly at $p<0.05$ in Tukey's honest significant difference (HSD) test. The absence of letters denotes non-significant differences. 
The WSC content of grass biomass is significantly influenced by $\mathrm{N}$ fertilization. In the present study, WSC accumulation was highest in perennial ryegrass fertilized with $120 \mathrm{~kg} \mathrm{~N} \mathrm{ha}^{-1}$. An increase in $\mathrm{N}$ fertilizer rate to $240 \mathrm{~kg} \mathrm{ha}^{-1}$ led to a decrease in WSC concentrations in both analyzed cultivars (by over 20\% on average, Table 2) in all years of the study, particularly in the second year, which was characterized by considerable rainfall deficiency during the growing season. Similar results were reported by Chesney et al. [41], Conaghan et al. [42], Lattanzi et al. [43], Ciepiela [44] and Ciepiela et al. [45]. According to the cited authors, $\mathrm{N}$ fertilization decreases WSC concentrations because carbohydrates are used for the production of nitrogen compounds in plants. Under a prolonged drought condition, carbohydrates support plant growth and contribute to maintaining physiological processes in plants [4]. It should be noted, however, than under increased physiological stress conditions, $\mathrm{N}$ supports plant development, which increases the rate of photosynthesis and the WSC content of plants in the long term [46].

In the temperate climate (NE Poland), WSC concentrations in leaf blades are highest in the evening and lowest in the morning. The differences between morning and evening harvests are small in traditional cultivars of perennial ryegrass, but much greater in cultivars with increased WSC content $[47,48]$. In the current study, plants harvested at noon (12.00-2.00) and in the afternoon (4.00-6.00) accumulated more WSC than those harvested in the morning (8.00-10.00). An analysis of the mean values over three years demonstrated that the differences in WSC concentrations between biomass samples harvested at 8.00-10.00 a.m. and 12.00-2.00 p.m., and at 8.00-10.00 a.m. and 4.00-6.00 p.m. reached 5.6\% and $5.2 \%$, respectively. However, significant differences in this parameter were noted only in the first year of the study, when its values were higher by $20.1 \%$ and $17.2 \%$, respectively (Table 2). A significant effect of harvest time on the WSC content of grass biomass was also observed by Bryant et al. [47], Trevaskis et al. [49] and Orr et al. [19]. Bryant et al. [47] found that WSC concentrations in perennial ryegrass increased by $20 \%$ between morning and afternoon. Trevaskis et al. [49] reported that the WSC content of plant materials was by $52 \mathrm{~g} \mathrm{~kg}^{-1} \mathrm{DM}$ higher in the afternoon than in the morning. In a study by Orr et al. [19], WSC concentrations in grass herbage were significantly higher in the afternoon than in the morning (204 $\mathrm{g} \mathrm{kg}^{-1}$ DM vs. $175 \mathrm{~g} \mathrm{~kg}^{-1} \mathrm{DM}$ ).

In the present experiment, the WSC content of perennial ryegrass varied across harvests. In all years of the study, third-cut herbage accumulated the lowest amounts of WSC. An analysis of mean values throughout the experiment revealed that WSC concentrations were highest in first-cut herbage, and significantly lower in second-cut and fourth-cut herbage. No significant differences in WSC content were found between second-cut and fourth-cut herbage (Table 2). Similar changes in WSC concentrations in grass regrowths were observed by Truba et al. [50], Purwin et al. [51], Ciepiela [44], Lessire et al. [52] and Gilliland et al. [7].

An interaction between cultivar and fertilization revealed that both cultivars of perennial ryegrass responded similarly to the applied $\mathrm{N}$ fertilizer rates (Figure 1). Baronka and Bajka accumulated the largest amounts of WSC at the $\mathrm{N}$ rate of $120 \mathrm{~kg} \mathrm{ha}^{-1}$. However, cv. Bajka responded to an increase in N rate with a greater decrease in the WSC content of biomass than cv. Baronka (23.2\% vs. 19.1\%). It should be stressed that the decrease in WSC concentrations was lower in the absence of $\mathrm{N}$ fertilization than when $\mathrm{N}$ fertilizer was applied at $240 \mathrm{~kg} \mathrm{ha}^{-1}$. Harvest time exerted a similar effect on WSC accumulation in both tested cultivars of perennial ryegrass. In both cultivars, the WSC content of aboveground biomass was higher when harvest was carried out at noon and in the afternoon than in the morning, whereas no significant differences in WSC accumulation were noted between harvest times of 12.00-2.00 p.m. and 4.00-6.00 p.m. In both the tetraploid cultivar Baronka and the diploid cultivar Bajka, WSC concentrations were highest in first-cut herbage and lowest in third-cut herbage. The differences in WSC content between the first and the third harvest reached 55.7\% in cv. Baronka and 44.4\% in cv. Bajka. No significant differences in WSC concentrations were found between the cultivars across harvests. The WSC con- 
tent of biomass was highest in 2014 in both cultivars, and it was significantly higher (by approximately $11 \%$ ) in cv. Baronka (Figure 1).
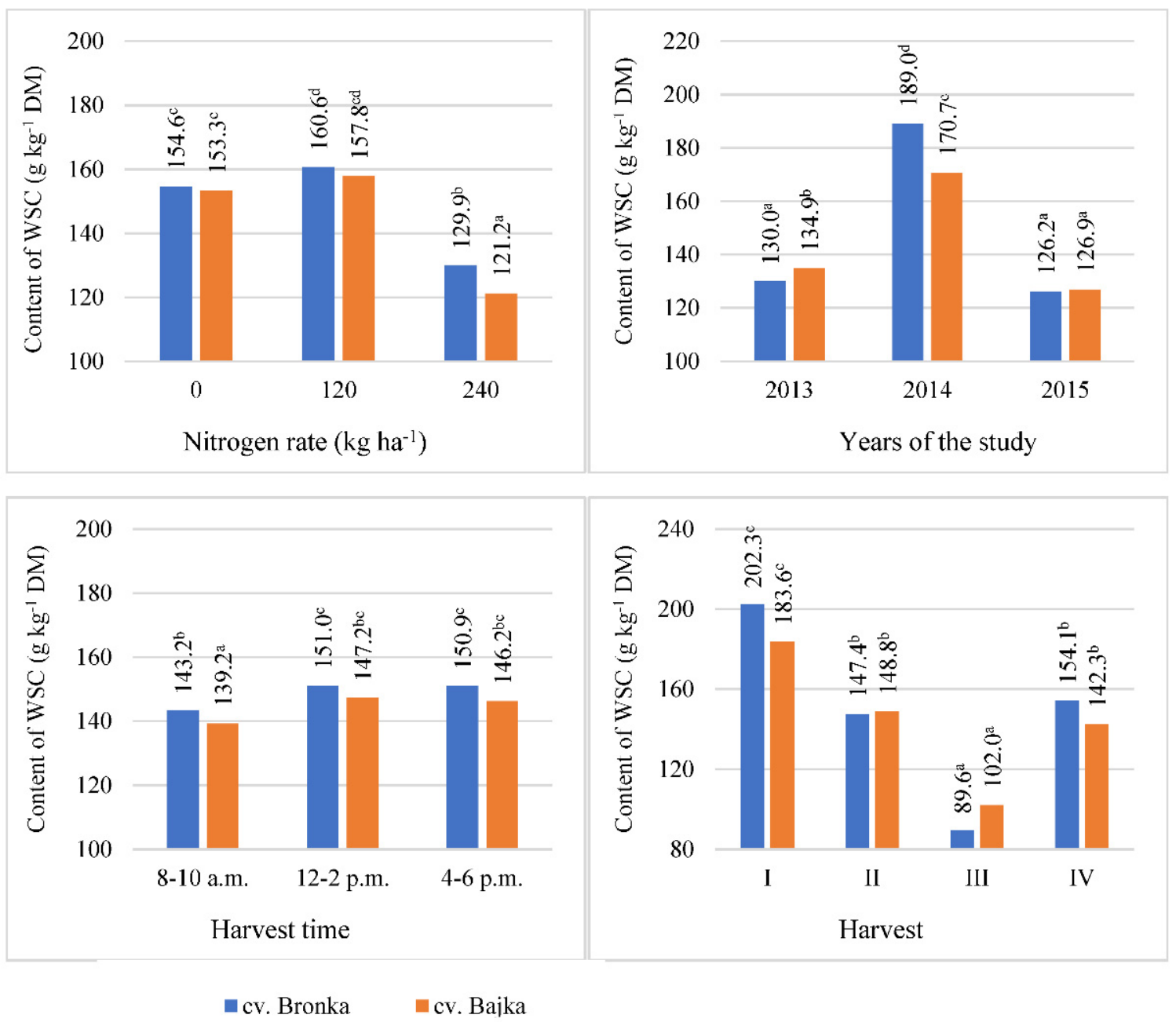

Figure 1. Relationships between the content of water-soluble carbohydrates (WSC, $\mathrm{g} \mathrm{kg}^{-1} \mathrm{DM}$ ) in the post-harvest biomass of the analyzed perennial ryegrass cultivars vs. nitrogen rate, harvest time and years of the study. Means with the same letter do not differ significantly at $p<0.05$ in Tukey's honest significant difference (HSD) test. The absence of letters denotes non-significant differences.

\subsection{Crude Protein $(C P)$}

The average $\mathrm{CP}$ content of perennial ryegrass biomass, calculated over the three-year experimental period, was $143.4 \mathrm{~g} \mathrm{~kg}^{-1} \mathrm{DM}$ in cv. Bajka and $138.7 \mathrm{~g} \mathrm{~kg}^{-1} \mathrm{DM}$ in cv. Baronka. In the first year of full utilization, no significant differences in $\mathrm{CP}$ content were found between the cultivars. The diploid cultivar Bajka had higher $\mathrm{CP}$ concentrations in the second and third year of the study, and the greatest difference in $\mathrm{CP}$ content between the cultivars (5.5\%) was noted in the second year of full utilization (Table 3). It should be stressed that the growing season of 2014 was characterized by adverse hydrothermal conditions, which contributed to the manifestation of varietal traits. Different results were reported by Balocchi and López [2] in whose study, $\mathrm{CP}$ concentrations in perennial ryegrass biomass were similar in tetraploid and diploid cultivars. According to the above authors, the soil and climatic conditions of Southern Chile were conducive to $\mathrm{CP}$ accumulation in plants. In the present experiment, the $\mathrm{CP}$ content of perennial ryegrass biomass was significantly affected by $\mathrm{N}$ fertilization (Table 3 ). Both the lower and higher $\mathrm{N}$ rate increased $\mathrm{CP}$ concentrations on a DM basis, by around $4 \%$ and $28 \%$, respectively. In the first and second year of the study, a minor decrease in $\mathrm{CP}$ content was observed in both cultivars 
in the lower $\mathrm{N}$ rate treatment, relative to the control treatment. An increase in $\mathrm{N}$ rate to $240 \mathrm{~kg} \mathrm{ha}{ }^{-1}$ contributed to the accumulation of CP in herbage. The CP content of biomass increased by $16 \%, 14 \%$ and $43 \%$ in successive years. Harvest time induced minor differences in CP concentrations, which were lowest in plants harvested in the morning (8.00-10.00), and significantly higher in plants harvested at noon (12.00-2.00) and in the afternoon (4.00-6.00). The differences relative to the morning harvest reached $1 \%$ and $2 \%$, respectively (Table 3). In contrast, Delagarde et al. [53] found that the CP content of perennial ryegrass sward was significantly higher in the morning than in the evening, and the effect of the time of day was more pronounced in spring than in autumn. In the current study, CP accumulation varied significantly between harvests. The CP content of biomass in the tested cultivars increased significantly between the first and subsequent harvests, by around $15 \%, 24 \%$ and $41 \%$, respectively (Table 3 ). The present results are consistent with the findings of Pirhofer-Walzl et al. [54]. According to Schlegel et al. [55], CP concentrations in grass biomass increase with successive harvests due to the transition from generative to vegetative growth.

Table 3. Content of crude protein (CP) in perennial ryegrass biomass ( $\left.\mathrm{g} \mathrm{kg}^{-1} \mathrm{DM}\right)$.

\begin{tabular}{|c|c|c|c|c|}
\hline \multirow{2}{*}{ Parameter } & \multicolumn{3}{|c|}{ Years of the Study } & \multirow{2}{*}{ Mean } \\
\hline & 2013 & 2014 & 2015 & \\
\hline \multicolumn{5}{|c|}{ Cultivar } \\
\hline Baronka & $143.1^{\mathrm{a}}$ & $127.2^{\mathrm{a}}$ & $145.6^{\mathrm{a}}$ & $138.7^{\mathrm{a}}$ \\
\hline Bajka & $144.7^{\mathrm{a}}$ & $134.2^{b}$ & $151.1^{b}$ & $143.4^{\mathrm{b}}$ \\
\hline \multicolumn{5}{|c|}{ Nitrogen rate $\left(\mathrm{kg} \mathrm{ha}^{-1}\right)$} \\
\hline 0 & $137.4^{\mathrm{a}}$ & $122.3^{b}$ & $123.8^{a}$ & $127.8^{\mathrm{a}}$ \\
\hline 120 & $135.5^{\mathrm{a}}$ & $116.6^{\mathrm{a}}$ & $144.6^{\mathrm{b}}$ & $132.2^{b}$ \\
\hline 240 & $158.8^{b}$ & $153.4^{\mathrm{C}}$ & $176.7^{\mathrm{c}}$ & $163.0^{\mathrm{c}}$ \\
\hline \multicolumn{5}{|c|}{ Harvest time } \\
\hline 8.00-10.00 a.m. & $143.8^{\mathrm{a}}$ & $130.0^{a b}$ & $144.9^{\mathrm{a}}$ & $139.6^{\mathrm{a}}$ \\
\hline 12.00-2.00 p.m. & $144.6^{\mathrm{a}}$ & $128.8^{a}$ & $149.9^{b}$ & $141.1^{\mathrm{ab}}$ \\
\hline $4.00-6.00$ p.m. & $143.4^{\mathrm{a}}$ & $133.3^{b}$ & $150.4^{b}$ & $142.4^{\mathrm{b}}$ \\
\hline \multicolumn{5}{|c|}{ Harvest } \\
\hline I & $132.0^{\mathrm{a}}$ & $108.6^{\mathrm{a}}$ & $111.7^{\mathrm{a}}$ & $117.4^{\mathrm{a}}$ \\
\hline II & $134.7^{\mathrm{a}}$ & $118.9^{\mathrm{b}}$ & $151.1^{\mathrm{b}}$ & $134.9^{b}$ \\
\hline III & $145.6^{\mathrm{b}}$ & $141.8^{\mathrm{c}}$ & $149.8^{\mathrm{b}}$ & $145.7^{\mathrm{c}}$ \\
\hline IV & $163.3^{c}$ & $153.7^{\mathrm{d}}$ & $181.0^{\mathrm{c}}$ & $166.0^{\mathrm{d}}$ \\
\hline
\end{tabular}

Means with the same letter do not differ significantly at $p<0.05$ in Tukey's HSD test. The absence of letters denotes non-significant differences.

An analysis of the interactions between the experimental factors revealed that both cultivars responded similarly to the applied rates of $\mathrm{N}$ fertilizer (Figure 2). The lower $\mathrm{N}$ rate $\left(120 \mathrm{~kg} \mathrm{ha}^{-1}\right)$ had no significant effect on the CP content of biomass in $\mathrm{cv}$. Baronka and cv. Bajka, whereas an increase in $\mathrm{N}$ rate to $240 \mathrm{~kg} \mathrm{ha}^{-1}$ significantly contributed to $\mathrm{CP}$ accumulation, and a stronger response was noted in cv. Bajka. In comparison with the control treatment, CP concentrations in cv. Bajka and cv. Baronka were $32 \%$ and $23 \%$ higher, respectively. In both cultivars, the CP content of biomass was affected by harvest time. In the diploid cultivar Bajka, CP concentrations on a DM basis were higher in herbage harvested at 12.00-2.00 p.m. and 4.00-6.00 p.m. In the tetraploid cultivar Baronka, biomass harvested at 4.00-6.00 p.m. had considerably higher CP content. In cv. Baronka, no significant differences in this parameter were found between samples harvested at 8.00-10.00 a.m. and 12.00-2.00 p.m. The present results indicate that CP concentrations in biomass can be increased by harvesting perennial ryegrass at noon and in the afternoon, although this is a varietal trait. In both cultivars, the CP content of biomass increased significantly with successive harvests. In both the diploid and tetraploid cultivar, $\mathrm{CP}$ concentrations were highest in fourth-cut herbage. In comparison with the first harvest, these values were $42 \%$ and $41 \%$ higher in cv. Baronka and cv. Bajka, respectively. 
The CP content of perennial ryegrass biomass was also significantly influenced by the year of the study. In both cultivars, this parameter was lowest in the second year, and significantly higher in the first and third year. The considerably lower $\mathrm{CP}$ concentrations noted in both cultivars in the second year of full utilization could be due a prolonged dry spell. The present findings also indicate that $\mathrm{cv}$. Baronka is more sensitive to unfavorable hydrothermal conditions than cv. Bajka. The decrease in the CP content of biomass was significantly greater in cv. Baronka than in cv. Bajka (Figure 2).
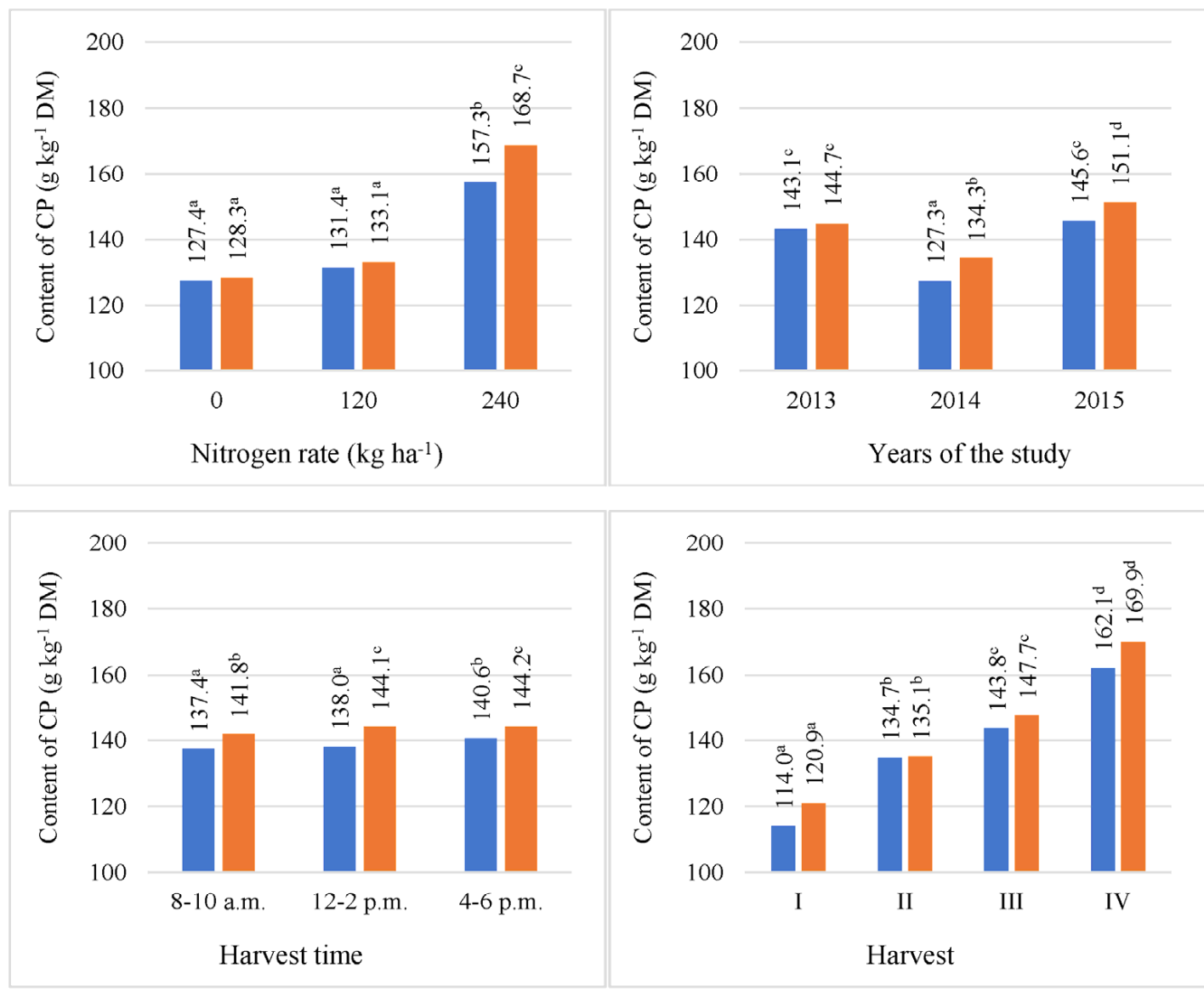

$$
\text { m. Bronka } \quad \text { cv. Bajka }
$$

Figure 2. Relationships between the content of crude protein $\left(\mathrm{g} \mathrm{kg}^{-1} \mathrm{DM}\right)$ in the post-harvest biomass of the analyzed perennial ryegrass cultivars vs. nitrogen rate, harvest time and years of the study. Means with the same letter do not differ significantly at $p<0.05$ in Tukey's honest significant difference (HSD) test. The absence of letters denotes nonsignificant differences.

\subsection{Carbohydrate-To-Protein Ratio}

The WSC:CP ratio in ruminant diets should range from 0.8 to 1.5 , and should not be lower than 0.4. According to Edwards et al. [23], the WSC:CP ratio exerts a greater effect on $\mathrm{N}$ use efficiency in ruminants that WSC concentrations in feed. Da Silva et al. $[27,56]$ noted an increase in N use efficiency when the WSC:CP ratio exceeded 0.7. Parsons et al. [22] demonstrated that the WSC:CP ratio of $0.5-2.4$ was negatively correlated with urinary N excretion. In the current study, the WSC:CP ratio remained within the optimal range of 0.88-1.50 (Table 4). On average, the WSC:CP ratio was higher in cv. Baronka. Significant differences in the WSC:CP ratio were noted between the cultivars only in the second year of full utilization, when its value was higher in the tetraploid cultivar Baronka than in the diploid cultivar Bajka. No such differences were found in the first and third year of the experiment. In all years of the study, the WSC:CP ratio was significantly affected by 
$\mathrm{N}$ fertilization. The data for 2013-2015 show that an increase in N rate to $240 \mathrm{~kg} \mathrm{ha}^{-1}$ had a negative effect on the WSC:CP ratio, decreasing its value by around $36 \%$ relative to the lower $\mathrm{N}$ rate $\left(120 \mathrm{~kg} \mathrm{ha}^{-1}\right)$ treatment and by around $35 \%$ relative to the control (unfertilized) treatment. Harvest time had a significant influence on the WSC:CP ratio only in the first year of the study. The WSC:CP ratio was significantly lowest in perennial ryegrass biomass harvested in the morning (8.00-10.00), whereas no differences were found between harvests carried out at noon and in the afternoon. The values of the WSC:CP ratio varied considerably between harvests-they were highest in first-cut herbage and significantly lowest in third-cut herbage. These relationships were particularly noticeable in the second and third years of the experiment (Table 4). Similar seasonal variations in the WSC:CP ratio were reported by Truba et al. [50].

Table 4. WSC:CP ratio in perennial ryegrass biomass.

\begin{tabular}{|c|c|c|c|c|}
\hline \multirow{2}{*}{ Parameter } & \multicolumn{3}{|c|}{ Years of the Study } & \multirow{2}{*}{ Mean } \\
\hline & 2013 & 2014 & 2015 & \\
\hline \multicolumn{5}{|c|}{ Cultivar } \\
\hline Baronka & $0.92^{a}$ & $1.5^{\mathrm{b}}$ & $0.90^{a}$ & $1.11^{\mathrm{b}}$ \\
\hline Bajka & $0.95^{\mathrm{a}}$ & $1.3^{\mathrm{a}}$ & $0.88^{a}$ & $1.05^{\mathrm{a}}$ \\
\hline \multicolumn{5}{|c|}{ Nitrogen rate } \\
\hline 0 & $1.01^{\mathrm{b}}$ & $1.45^{b}$ & $1.18^{\mathrm{c}}$ & $1.22^{b}$ \\
\hline 120 & $1.07^{\mathrm{c}}$ & $1.73^{\mathrm{c}}$ & $0.92^{b}$ & $1.24^{b}$ \\
\hline 240 & $0.72^{a}$ & $1.07^{\mathrm{a}}$ & $0.57^{\mathrm{a}}$ & $0.79^{c}$ \\
\hline \multicolumn{5}{|c|}{ Harvest time } \\
\hline 8.00-10.00 a.m. & $0.83^{a}$ & $1.40^{\mathrm{a}}$ & $0.91^{a}$ & $1.05^{\mathrm{a}}$ \\
\hline $12.00-2.00$ p.m. & $0.99^{b}$ & $1.45^{\mathrm{a}}$ & $0.87^{\mathrm{a}}$ & $1.09^{b}$ \\
\hline $4.00-6.00$ p.m. & $0.98^{b}$ & $1.40^{\mathrm{a}}$ & $0.90^{a}$ & $1.10^{b}$ \\
\hline \multicolumn{5}{|c|}{ Harvest } \\
\hline I & $0.95^{b}$ & $2.39^{\mathrm{d}}$ & $1.89^{\mathrm{c}}$ & $1.74^{\mathrm{d}}$ \\
\hline II & $1.12^{\mathrm{c}}$ & $1.61^{\mathrm{c}}$ & $0.81^{b}$ & $1.18^{c}$ \\
\hline III & $0.72^{a}$ & $0.70^{\mathrm{a}}$ & $0.62^{a}$ & $0.68^{a}$ \\
\hline IV & $0.99^{b}$ & $1.26^{b}$ & $0.61^{a}$ & $0.95^{b}$ \\
\hline
\end{tabular}

Means with the same letter do not differ significantly at $p<0.05$ in Tukey's HSD test. The absence of letters denotes non-significant differences.

An analysis of the cultivar $\times$ fertilization interactions revealed that the lower $\mathrm{N}$ rate had no effect on the WSC:CP ratio in the analyzed cultivars of perennial ryegrass (Figure 3). An increase in $\mathrm{N}$ rate to $240 \mathrm{~kg} \mathrm{ha}^{-1}$ led to a significant decrease in its value, and a stronger response was noted in cv. Bajka. In this cultivar, the WSC:CP ratio was $42 \%$ lower relative to the lower $\mathrm{N}$ rate and control treatments. Harvest time had a significant influence on the WSC:CP ratio in perennial ryegrass DM. In both cultivars, the WSC:CP ratio was lowest in herbage harvested in the morning. The biomass of $\mathrm{cv}$. Baronka harvested at noon (12.00-2.00) was characterized by the most desirable WSC:CP ratio. In cv. Bajka, no significant differences in the values of this parameter were found between biomass samples harvested at $12.00-2.00$ p.m. and $4.00-6.00$ p.m. Considerable variations in the WSC:CP ratio were noted between harvests. In both cultivars, the WSC:CP ratio was highest in first-cut herbage and lowest in third-cut herbage. The differences in the WSC:CP ratio between the first and the third harvest reached $66 \%$ in cv. Baronka and $55 \%$ in cv. Bajka. In both cultivars, the WSC:CP ratio was highest in 2014 (1.51 in cv. Baronka and $1.33 \mathrm{in} \mathrm{cv}$. Bajka). No significant differences in the WSC:CP ratio were observed between 2013 and 2015 in cv. Baronka, whereas cv. Bajka was characterized by the lowest WSC:CP ratio in 2015 (Figure 3). 

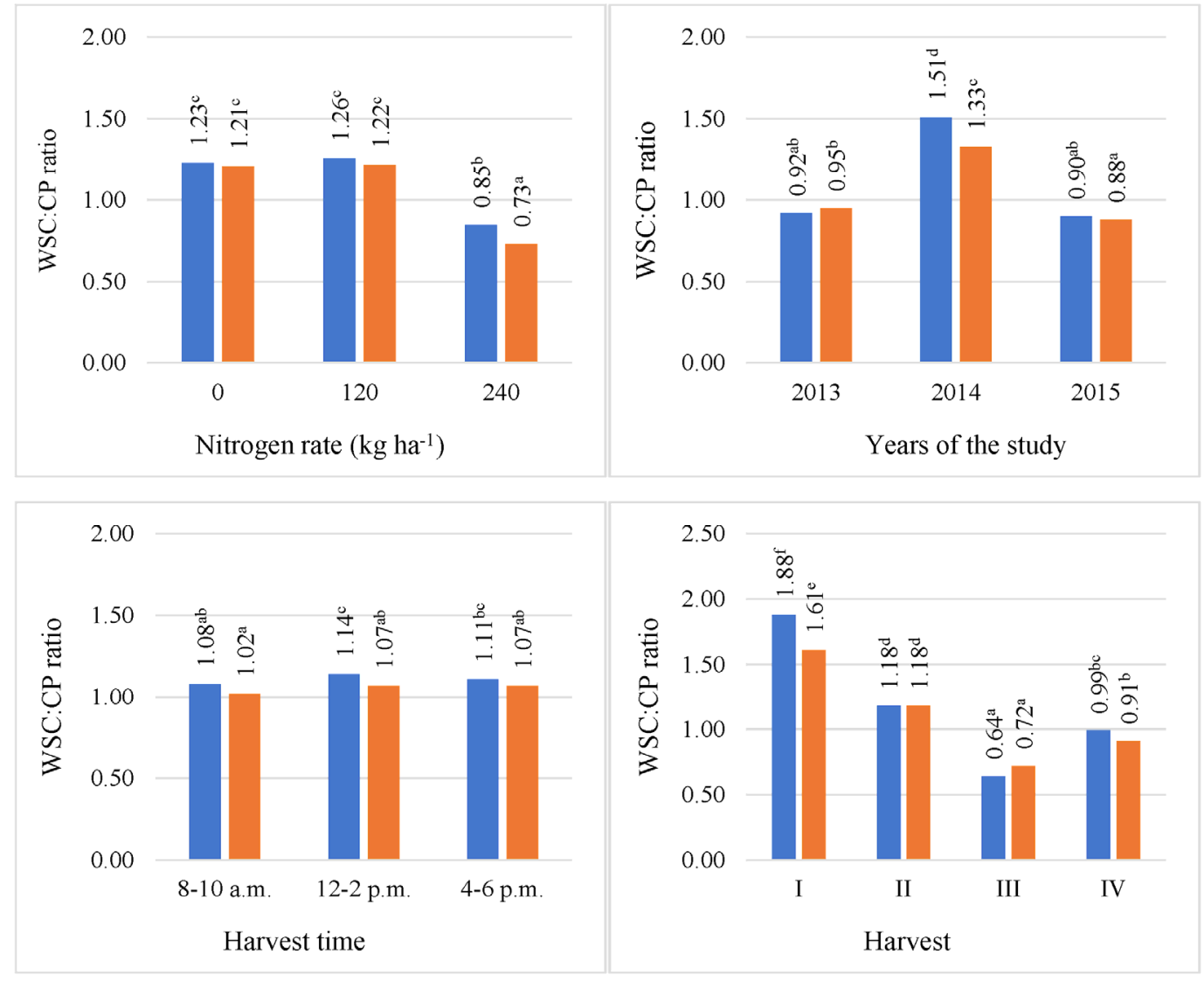

mcv. Bronka $\quad$ cv. Bajka

Figure 3. Relationships between the WSC:CP ratio in the post-harvest biomass of the analyzed perennial ryegrass cultivars vs. nitrogen rate, harvest time and years of the study. Means with the same letter do not differ significantly at $p<0.05$ in Tukey's honest significant difference (HSD) test. The absence of letters denotes non-significant differences.

\section{Conclusions}

The results of this study indicate that the genetic factor (cultivar) had a considerable influence on the content of WSC and CP in the aboveground biomass of perennial ryegrass. The tetraploid cultivar Baronka had higher WSC content and lower CP content on a dry matter basis than the diploid cultivar Bajka. These parameters had a significant effect on the WSC:CP ratio, which was higher in cv. Baronka. A high rate of $\mathrm{N}$ fertilizer $\left(240 \mathrm{~kg} \mathrm{ha}^{-1}\right)$ contributed to a decrease in WSC concentrations and to an increase in the CP content of biomass in both cultivars, and it negatively affected the WSC:CP ratio. A stronger response was noted in the diploid cultivar Bajka. Both cultivars accumulated significantly higher WSC amounts when biomass was harvested at noon and in the afternoon than in the morning. Crude protein accumulation in biomass was also affected by harvest time, and it was higher in cv. Bajka when harvest was carried out at 12.00-2.00 p.m. and 4.00-6.00 p.m., and in cv. Baronka when harvest was carried out at 4.00-6.00 p.m. In both cultivars, biomass harvested in the morning (8.00-10.00) was characterized by the lowest WSC:CP ratio. The values of the analyzed parameters varied considerably across the growing season in both cultivars. The concentrations of WSC and the WSC:CP ratio were highest in first-cut herbage and lowest in third-cut herbage. The values of the analyzed parameters were also determined by weather conditions. The hydrothermal conditions in the second year of the study (2014) supported WSC biosynthesis and limited CP biosynthesis in perennial ryegrass. The WSC:CP ratio was optimal in 2014 in both cultivars, and it reached a significantly higher value in the tetraploid cultivar Baronka. The present findings show that the feed value of perennial ryegrass was significantly affected 
by the experimental factors, which has important practical implications. The selection of cultivars that are well adapted to the local environmental conditions, and the optimization of $\mathrm{N}$ rate and harvest date contribute to producing forage characterized by high nutritional value without increasing production costs.

Funding: The results presented in this paper were obtained as part of a comprehensive study financed by the University of Warmia and Mazury in Olsztyn (grant No. 20.610.011-110). Project financially supported by Minister of Science and Higher Education in the range of the program entitled 'Regional Initiative of Excellence' for the years 2019-2022, project No. 010/RID/2018/19, amount of funding 12.000.000 PLN.

Institutional Review Board Statement: Not applicable.

Informed Consent Statement: Not applicable.

Data Availability Statement: Not applicable.

Acknowledgments: The author would like to thank the staff of the Agricultural Experiment Station in Tomaszkowo for technical support during the experiment.

Conflicts of Interest: The author declare no conflict of interest.

\section{References}

1. Brzóska, F.; Śliwiński, B. Quality of roughages in ruminants nutrition and methods for its evaluation. Part I. Characteristics of roughages and measures of their quality. Wiad. Zoot. 2011, 2, 11-23. (In Polish)

2. Balocchi, O.A.; López, I.F. Herbage production, nutritive value and grazing preference of diploid and tetraploid perennial ryegrass cultivars (Lolium perenne L.). Chil. J. Agric. Res. 2009, 69, 331-339. [CrossRef]

3. Sandrin, C.Z.; Domingos, M.; Figueiredo-Ribeiro, R.D.C.L. Partitioning of water soluble carbohydrates in vegetative tissues of Lolium multiflorum Lam. ssp. italicum cv. Lema. Braz. J. Plant Physiol. 2006, 18, 299-305. [CrossRef]

4. Turner, L.R.; Holloway-Philips, M.M.; Rawnsley, R.P.; Donaghy, D.J.; Pembleton, K.G. The morphological and physiological responses of perennial ryegrass (Lolium perenne L.), cocksfoot (Dactylis glomerata L.) and tall fescue (Festuca arundinacea Schreb.; syn. Schedonorus phoenix Scop.) to variable water availability. Grass Forage Sci. 2012, 67, 507-518. [CrossRef]

5. Jones, E.L.; Roberts, J.E. A note on the relationship between palatability and water-soluble carbohydrates content in perennial ryegrass. Irish J. Agric. Food Res. 1991, 30, 163-167.

6. Stewart, A.; Hayes, R. Ryegrass breeding-balancing trait priorities. Irish J. Agric. Food Res. 2011, 50, 31-46.

7. Gilliland, T.J.; Barrett, P.D.; Mann, R.L.; Agnew, R.E.; Fearon, A.M. Canopy morphology and nutritional quality traits as potential grazing value indicators for Lolium perenne varieties. J. Agric. Sci. 2002, 139, 257-273. [CrossRef]

8. Turner, L.R.; Donaghy, D.J.; Pembleton, K.G.; Rawnsley, R.P. Longer defoliation interval ensures expression of the 'high sugar' trait in perennial ryegrass cultivars in cool temperate Tasmania, Australia. J. Agric. Sci. 2015, 153, 995-1005. [CrossRef]

9. Jafari, A.A.; Rezaeifard, M. Effects of maturity on yield and quality traits in tall fescue (Festuca arundinace Schreb). Am. Eurasian J. Agric. Environ. Sci. 2010, 9, 98-104.

10. Rezaeifard, M.; Jafari, A.A.; Assareh, M.H. Effects of phenological stages on forage yield quality traits in cocksfoot. J. Food Agric. Environ. 2010, 8, 365-369.

11. Gilliland, T.; Johnson, J.; Connolly, C. A review of forage grass and clover seed use in Northern Ireland, UK, between 1980 and 2004. Grass Forage Sci. 2007, 62, 239-254. [CrossRef]

12. Smith, K.F.; Simpson, R.J.; Culvenor, R.A.; Humphreys, M.O.; Prud' Homme, P.; Oram, R.N. The effects of ploidy and a phenotype conferring a high water-soluble carbohydrate concentration on carbohydrate accumulation, nutritive value and morphology of perennial ryegrass (Lolium perenne L.). J. Agric. Sci. 2001, 136, 65-74. [CrossRef]

13. Dijkstra, J.; Oenema, O.; Bannink, A. Dietary strategies to reducing N excretion from cattle: Implications formethane emissions. Curr. Opin. Environ. Sustain. 2011, 3, 414-422. [CrossRef]

14. Evans, J.G.; Fraser, M.D.; Owen, I.; Davies, D.A. An evaluation of two perennial ryegrass cultivars (AberDartand and Fennema) for sheep production in the uplands. J. Agric. Sci. 2011, 149, 235-248. [CrossRef]

15. Cosgrove, G.P.; Burke, J.L.; Death, A.F.; Hickey, M.J.; Pacheco, D.; Fraser, K.; Lane, G.A. Ryegrass with increased water soluble carbohydrate: Evaluating the potential for grazing dairy cows in New Zealand. Proc. N. Z. Grassl. Assoc. 2007, 69, 179-185.

16. Tas, B.M.; Taweel, H.Z.; Smit, H.J.; Elgersma, A.; Dijkstra, J.; Tamminga, S. Effects of perennial ryegrass cultivars on milk yield and nitrogen utilization in grazing dairy cows. J. Dairy Sci. 2006, 89, 3494-3500. [CrossRef]

17. Miller, L.A.; Moorby, J.M.; Davies, D.R.; Humphreys, M.O.; Scollan, N.D.; Macrae, J.C.; Theodorou, M.K. Increased concentration of water-soluble carbohydrate in perennial ryegrass (Lolium perenne L.). Milk production from late-lactation dairy cows. Grass Forage Sci. 2001, 56, 383-394. [CrossRef] 
18. Lee, M.R.F.; Jones, E.L.; Moorby, J.M.; Humphreys, M.O.; Theodorou, M.K.; MacRae, J.C.; Scollan, N.D. Production responses from lambs grazed on Lolium perenne selected for an elevated water-soluble carbohydrate concentration. Anim. Res. 2001, 50, 441-449. [CrossRef]

19. Orr, R.J.; Rutter, S.M.; Penning, P.D.; Rook, A.J. Matching grass supply to grazing pattern for dairy cows. Grass Forage Sci. 2001, 56, 352-361. [CrossRef]

20. Baert, J.; van Waes, C. Improvement of the digestibility of tall fescue (Festuca arundinacea Schreb.) inspired by perennial ryegrass (Lolium perenne L.). Grassl. Sci. Eur. 2014, 19, 172-174.

21. Andrzejewska, J.; Albrecht, K.A.; Jędrzejczak, E. Plant height and feed value of alfalfa in different development stages and cuts. Fragm. Agron. 2013, 30, 14-22. (In Polish)

22. Parsons, A.J.; Edwards, G.R.; Newton, P.C.D.; Chapman, D.F.; Caradus, J.R.; Rasmussen, S.; Rowarth, J.S. Past lessons and future prospects: Plant breeding for yield and persistence in cool-temperate pastures. Grass Forage Sci. 2011, 66, 153-172. [CrossRef]

23. Edwards, G.R.; Parsons, A.J.; Rasmussen, S.; Bryant, R.H. High sugar ryegrasses for livestock systems in New Zealand. Proc. N. Z. Grassl. Assoc. 2007, 69, 161-171. [CrossRef]

24. Wilkins, P.W.; Humphreys, M.O. Progress in breeding perennial forage grasses for temperate agriculture. J. Agric. Sci. 2003, 140, 129-150. [CrossRef]

25. Valk, H.; Poelhuis, H.W.K.; Wentink, H.J. Effect of fibrous and starchy carbohydrates in concentrates as supplements in a herbage-based diet for high-yielding dairy cows. Neth. J. Agric. Sci. 1990, 38, 475-486. [CrossRef]

26. Loaiza, P.; Balocchi, O.; López, I.F. Changes in water-soluble carbohydrates relative to crude protein in perennial ryegrass in response to defoliation frequency. Grassland Sci. 2017, 63, 159-168. [CrossRef]

27. Da Silva, M.S.; Tremblay, G.F.; Bélanger, G.; Lajeunesse, J.; Papadopoulos, Y.A.; Fillmore, S.A.; Jobim, C.C. Forage energy to protein ratio of several legume-grass complex mixtures. Anim. Feed Sci. Technol. 2014, 188, 17-27. [CrossRef]

28. Huhtanen, P.; Broderick, G. Improving utilisation of forage protein in ruminant production by crop and feed management. Grass Forage Sci. 2016, 61, 340-349.

29. IUSS Working Group WRB. World Reference Base for Soil Resources, 2014, Update 2015. International Soil Classification System for Naming Soils and Creating Legends for Soil Maps; World Soil Resources Reports No. 106; FAO: Rome, Italy, 2015 ; p. 203.

30. Skowera, B.; Puła, J. Pluviometric extreme conditions in spring season in Poland in the years 1971-2000. Acta Agroph. 2004, 3, 171-177. (In Polish)

31. Thomas, T.A. An automated procedure for the determination of soluble carbohydrates in herbage. J. Sci. Food Agric. 1977, 28, 639-642. [CrossRef]

32. Houba, V.J.G.; Van der Lee, J.J.; Novozamsky, I. Soil and Plant Analysis; Part 5B. Soil Analysis Procedure other Procedure; Wageningen Agriculture University: Wageningen, The Netherlands, 1995.

33. TIBCO Software Inc. Statistica (Data Analysis Software System, Palo Alto, USA). 2017. Version 13.3. Available online: https: // docs.tibco.com/products/tibco-statistica-13-3-0 (accessed on 15 February 2021).

34. Blum, A.; Tuberosa, R. Dehydration survival of crop plants and its measurement. J. Exp. Bot. 2018, 69, 975-981. [CrossRef]

35. Da Costa, M.; Huang, B. Osmotic adjustment associated with variation in bentgrass tolerance to drought stress. J. Am. Soc. Hortic. Sci. 2006, 131, 338-344. [CrossRef]

36. Starck, Z. Plant responses to the abiotic environmental stresses-Aclimatization and adaptation. Łak. Pol. 2005, 8, 173-184. (In Polish)

37. Meisser, M.; Vitra, A.; Mosimann, E.; Deléglise, C.; Buttler, A. Linking functional plant traits and forage quality under drought conditions. Grassl. Sci. Eur. 2017, 22, 366-368.

38. Nazarli, H.; Faraji, F. Response of proline, soluble sugars and antioxidant enzymes in wheat to different irrigation regimes in greenhouse condition. Cercet. Agron. Mold. 2011, 4, 27-33. [CrossRef]

39. Weinberg, Z.G.; Bar-Tal, A.; Chen, Y.; Gamburg, M.; Brener, S.; Dvash, L.; Markovitz, T.; Landau, S. The effects of irrigation and nitrogen fertilization on the ensiling of safflower (Carthamus tinctorius). Anim. Feed Sci. Technol. 2007, 134, 152-161. [CrossRef]

40. Hume, D.E.; Hickey, M.J.; Lyons, T.B.; Baird, D.B. Agronomic performance and water-soluble carbohydrate expression of selected ryegrasses at two locations in New Zealand. N. Z. J. Agric. Res. 2010, 53, 37-57. [CrossRef]

41. Chesney, L.; Scollan, N.; Gordon, A.; McConnell, D.A.; Lively, F.O. Investigating the effect of nitrogen application level on grass production and quality under simulated grazing. Grassl. Sci. Eur. 2020, 25, 55-57.

42. Conaghan, P.; O'Kiely, P.; Halling, M.A.; O'Mara, F.P.; Nesheim, L. Yield and quality response of perennial ryegrass selected for high concentration of water-soluble carbohydrate to nitrogen application rate. Crop. Sci. 2012, 52, 28-39. [CrossRef]

43. Lattanzi, F.A.; Ostler, U.; Wild, M.; Morvan-Bertrand, A.; Decau, M.L.; Lehmeier, C.A.; Meuriot, F.; Proud'homme, M.P.; Schaufele, R.; Schnyder, H. Flexes in central carbohydrate metabolism of source leaves in a fructan-Storing C3 grass: Rapid turnover and futile cycling of sucrose in continuous light under contrasted nitrogen nutrition status. J. Exp. Bot. 2012, 63, 2363-2375. [CrossRef]

44. Ciepiela, G.A. Content of structural and nonstructural carbohydrates and lignin in Dactylis glomerata L. and Festulolium braunii (K. Richt.) A. Camus supplied by biostimulator Kelpak SL and nitrogen. Nauka Przyr. Technol. 2014, 8, 1-12. (In Polish)

45. Ciepiela, G.A.; Jankowski, K.; Jodełka, J. Effect of various nitrogen fertilisation forms on perennial ryegrass (Lolium perenne L.) yielding and content of carbohydrates and some nitrogen forms. Acta Sci. Pol. Agric. 2003, 2, 131-139. (In Polish)

46. Lee, J.M.; Donaghy, D.J.; Roche, J.R. The effect of grazing severity and fertiliser application during winter on herbage regrowth and quality of perennial ryegrass (Lolium perenne L.). Aust. J. Exp. Agric. 2007, 47, 825-832. [CrossRef] 
47. Bryant, R.H.; Gregorini, P.; Edwards, G.R. Effects of N fertilisation, leaf appearance and time of day on $\mathrm{N}$ fractionation and chemical composition of Lolium perenne cultivars in spring. Anim. Feed Sci. Technol. 2012, 173, 210-219. [CrossRef]

48. Griggs, T.C.; MacAdam, J.W.; Mayland, H.F.; Burns, J.C. Nonstructural carbohydrate and digestibility patterns in temperate pastures and canopy management implications. In Proceedings of the AFGC Annual Conference, French Lick, IN, USA, 12-15 June 2011.

49. Trevaskis, L.M.; Fulkerson, W.J.; Nandra, K.S. Effect of time of feeding carbohydrate supplements and pasture on production of dairy cows. Liv. Prod. Sci. 2004, 85, 275-285. [CrossRef]

50. Truba, M.; Jankowski, K.; Wiśniewska-Kadżajan, B.; Malinowska, E. The effect of soil conditioners on the content of soluble carbohydrates, digestible protein and the carbohydrate-protein ratio in Lolium perenne and Dactylis glomerata. Environ. Prot. Natur. Res. 2018, 29, 1-8.

51. Purwin, C.; Stanek, M.; Lipiński, K.; Wierzbowska, J.; Nogalska, A.; Fijalkowska, M. Effect of a harvest time and cultivar on the chemical composition and in vitro ruminal dry matter degradability of perennial ryegrass (Lolium perenne L.). J. Elem. 2016, 21, 811-822.

52. Lessire, F.; Hornick, J.L.; Dufrasne, I. Effects of concentrate levels on milk production and traffic of cows milked by a mobile automatic milking system on pasture. Grassl. Sci. Eur. 2014, 19, 545-549.

53. Delagarde, R.; Peyraud, J.L.; Delaby, L.; Faverdin, P. Vertical distribution of biomass, chemical composition and pepsin-cellulase digestibility in a perennial ryegrass sward: Interaction with month of year, regrowth age and time of day. Anim. Feed Sci. Technol. 2000, 84, 49-68. [CrossRef]

54. Pirhofer-Walzl, K.; Søegaard, K.; Høgh-Jensen, H.; Eriksen, J.; Sanderson, M.A.; Rasmussen, J.; Rasmussen, J. Forage herbs improve mineral composition of grassland herbage. Grass Forage Sci. 2011, 66, 415-423. [CrossRef]

55. Schlegel, P.; Wyss, U.; Arrigo, Y.; Hess, H.D. Mineral concentrations of fresh herbage from mixed grassland as influenced by botanical composition, harvest time and growth stage. Anim. Feed Sci. Tech. 2016, 219, 226-233. [CrossRef]

56. Da Silva, M.S.; Tremblay, G.F.; Bélanger, G.; Lajeunesse, J.; Papadopoulos, Y.A.; Fillmore, S.A.E.; Jobim, C.C. Energy to protein ratio of grass-legume binary mixtures under frequent clipping. Agron. J. 2013, 105, 482-492. [CrossRef] 